\title{
DEVELOPMENT OF MAIN PRINCIPLES AND TASKS OF JEWISH NATIONAL MOVEMENT FOR REVIVAL OF THE STATE BY VLADIMIR ZHABOTINSKY
}

\section{Lyudmyla Radchenko ${ }^{1}$}

${ }^{1}$ Department of Tourism and Social Humanities Sciences, Kharkiv College of Trade and Economics, Kyiv National University of Trade and Economics, Kharkiv, Ukraine,

kharkiv@htek.com.ua

ORCID:https://orcid.org/0000-0002-2514-7549

\begin{tabular}{l} 
ARTICLE INFO \\
\hline Article history: \\
Received date 09.03 .2021 \\
Accepted date 20.04 .2021 \\
Published date 30.04 .2021 \\
Section: \\
History \\
D O I \\
\hline $10.21303 / 2313-8416.2021 .001785$
\end{tabular}

KE Y W OR D S

Jewish politician

consolidation

Jewish national movement

revival of statehood

\section{A B S T RACT}

The social and political activity of V. Zhabotinsky as a Jewish politician, a famous Zionist, the founder of modern Israel and a multifaceted personality. Its focus on the consolidation of Jewish political and social organizations, the development of a common platform on the basic principles and objectives of the Jewish national movement for the revival of statehood and the involvement of Jews from around the world in this process is substantiated. V. Zhabotinsky's commitment to the Ukrainian national movement is proved.

The object of research: V. Zhabotinsky as a great political figure of the Jewish and Ukrainian national movement.

Investigated problem: V. Zhabotinsky contribution to the consolidation of Jewish political and public organizations, to the development of Zionist theory, the basic principles and tasks of the Jewish national movement for the revival of the independent Jewish state of Israel and the solution of the Ukrainian national question.

The main scientific results: based on the analysis of socio-political activities and creative achievements of V. Zhabotinsky as a Jewish politician, his focus on defining a common platform on the basic principles and tasks of the Jewish national movement for the revival of statehood, involving Jews from around the world. V. Zhabotinsky's commitment to the Ukrainian national movement was revealed.

The area of practical use of the research results: determined by the suitability for practical use of modern Jewish political and public organizations to preserve Jewish national identity, ideology and organization of the revisionist movement, as well as to address the Ukrainian issue of bilateral relations, understanding nationalism as a great life idea has nothing to do with chauvinism, racism or any form of ethical supremacy.

The results can be used in the development and teaching of courses: "World History" and "History of Ukraine".

Innovative technological product: on the basis of numerous sources and materials, some of which are introduced into scientific circulation for the first time, the V. Zhabotinsky Institute (Tel Aviv) has filled a significant gap in V. Zhabotinsky 's contribution as a great figure of the Jewish national movement. His commitment to the Ukrainian national movement is substantiated, the myth of eternal antagonism between Jews and Ukrainians is refuted, arguing that the two people have lived on Ukrainian lands for thousands of years.

Scope of the innovative technological product: theoretical research, development of $\mathrm{Zi}$ onist theory and practice of preserving Jewish national identity, ideology and organization of the revisionist movement, solution of the Ukrainian national question.

(C) The Author(s) 2021. This is an open access article under the Creative Commons CC BY license

\section{Introduction}

\section{1. The object of research}

Significant socio-political activity of V. Zhabotinsky's made a significant contribution to the development of a common platform on the basic principles and tasks of the Jewish national movement for the revival of the independent state of Israel, the involvement of Jews from around the world. He was committed to the Ukrainian national movement, which was oppressed by the Russian imperial authorities. 


\section{2. Problem description}

Studies of socio-political activity and scientific and journalistic heritage, creative achievements of V. Zhabotinsky characterize his significant contribution to the consolidation of Jewish political and public organizations, the development of Zionist theory, the definition of a common platform on the basic principles and objectives of the Jewish national movement for the revival of the Jewish independent state and the solution of the Ukrainian national question.

In the modern period, V. Zhabotinsky 's contribution to the development of the Zionist theory, the creation of an independent state of Israel, and his views on the relationship between Ukrainians and Jews deserve further study. Socio-political activities of V. Zhabotinsky as a Jewish politician [1, 2], a famous Zionist [3, 4], the founder of modern Israel, a revisionist is devoted to scientific works [1, 3, 5-7]. Its focus on the consolidation of Jewish political and social organizations [8], the development of a common platform on the basic principles and objectives of the Jewish national movement for the revival of statehood [9] and the involvement of Jews from around the world is considered in the works of scholars [10,11].

Theorists in their works analyze the activities of V. Zhabotinsky as one of the leaders of the Zionist movement, ideologue and founder of the revisionist movement in Zionism [4], and also characterize him as a fighter for the creation of the state of Israel [12]. His socio-political activities and creativity continue to be studied by foreign $[13,14]$ and domestic scholars $[15,16]$.

\subsection{Suggested solution to the problem}

The problem of V. Zhabotinsky 's contribution as a great figure of the Jewish national movement can be solved on the basis of substantiation of the basic principles and tasks of the Jewish national movement for the revival of the independent Jewish state and the Ukrainian national question.

The aim of the study is to substantiate the contribution of V. Zhabotinsky in the development of Zionist theory and practice of creating a Jewish state, in solving the Ukrainian national question.

\section{Materials and Methods}

The methodological basis of the study is a system of scientific principles, approaches and methods of cognition, aimed at a comprehensive study of socio-political phenomena, facts, events, objective reproduction and analysis of historical realities. The work is based on the fundamental principles of scientific knowledge: historicism, system, comprehensiveness, alternativeness.

This allowed to reveal the features and contribution of V. Zhabotinsky as a great figure of the Jewish and Ukrainian national movement for the creation of the Jewish state, in solving the Ukrainian national question.

The research was carried out by analyzing and generalizing social and political activities and scientific and journalistic heritage, creative achievements of V. Zhabotinsky on the basis of analytical and information sources.

\section{Results}

V. Zhabotinsky is known in the world as a prominent public and political figure, one of the leaders of the Zionist movement, ideologist and founder of the revisionist current in Zionism, an uncompromising fighter for the creation of the state of Israel. But very little is known about him in Ukraine today, because his name was banned in the Soviet Union. His name evoked associations with the Olympic Games and weightlifter Leonid Zhabotinsky. Even in the "Great Soviet Encyclopedia" about V. Zhabotinsky there is not a single sentence.

V. Zhabotinsky (Ze'ev) was born in Odessa on October 18, 1880. His father from Nikopol, was a grain buyer, one of those who created the trade wealth of the city, his mother was from Berdychiv [1].

Odessa at the end of the $19^{\text {th }}$ century, where the future leader of the national movement grew up, was a "mixture" of Russian, Ukrainian, Jewish, and Mediterranean cultures. At first V. Zhabotinsky studied at the Second Odessa Gymnasium, then moved to Richelieu. He read "serious" literature: Dickens, Zola, George Eliot. The young Zhabotinsky practically memorized three authors: Shakespeare, Pushkin and Lermontov. The boundary between childhood and adolescence was marked by Goncharov's novel "The Precipice", and among the favorite authors of world poetry were the poems of Mickiewicz and Edgar Allan Poe [1]. With a freedom-loving and independent 
character, he did not accept the order of teachers who were deluded by discipline, with whom there were constant conflicts.

In 1897, his first article was published, entitled "Pedagogical Remarks," which criticized the assessment system in schools. This is how Zhabotinsky, a publicist, appeared, who will soon be called the "Golden Pen" in Odessa for his sharp tongue and sarcastic style [1].

V. Zhabotinsky received his higher education thanks to his literary talent and linguistic abilities (he spoke ten foreign languages), and at the age of 18 he became a foreign correspondent for the "Odessky Listok" and "Odessky Noviny" newspapers, first in Bern and then in Rome.

The Jewish pogroms in Russia in 1903-1905 led V. Zhabotinsky to the Zionist movement. In 1923, on his way to Italy, passing a strip of settlement and meeting with representatives of the disenfranchised Jewish people, he noted for himself a lack of pride, inability to revolt. V. Zhabotinsky's hero was Giuseppe Garibaldi, a fearless fighter against tyranny, a "knight of humanity." In 1923, a Jewish pogrom took place in Chisinau; in Odessa, too, there were alarming rumors, the first self-defense units were created, in which the famous journalist also took part. Having visited the places of the Chisinau massacre as a correspondent, having got acquainted with the figures of the Jewish national movement, V. Zhabotinsky became a convinced Zionist. And all his further life - the struggle for the liberation of his people, the awakening of national consciousness in it and, ultimately - for the creation of a nation-state.

He joined the Jewish self-defense, collecting money to buy weapons. After studying Hebrew, V. Zhabotinsky in 1904 translated into Russian "The Tale of the Pogrom" H. N. Bjalik.

In 1903, V. Zhabotinsky moved to St. Petersburg, where he became a member of the editorial board of the magazine "Jewish Life", and later - the magazine "Svitanok (Dawn)". He took an active part in the creation of the Union to achieve the full rights of the Jewish people in Russia (1905) and the development of the Helsinki Program (1906) [1].

At the beginning of the First World War, V. Zhabotinsky went to Western Europe as a correspondent for the Moscow newspaper Russkie Vedomosti. After Turkey's entry into the war, he launched a campaign on the German side (October 1914) to establish a Jewish national military unit as part of the Allied forces. In 1917, the British government agreed to such combat units within the British Armed Forces. V. Zhabotinsky joined the Jewish Legion as a private, took a sergeant's course, and later received the rank of officer. He fought in the Jewish Legion of the British Army, which he distinguished himself in the battles against Turkish troops in Palestine. After the war, he created the Jewish self-defense of Gagan in Jerusalem, and with it the youth movement "Bethar". On the eve of World War II, Betar had about 100,000 members in Palestine and Europe [1].

These units later became the nucleus of the Israeli armed forces. In 1920, self-defense repulsed Arab extremists who tried to stage a pogrom. For this action, a military court sentenced V. Zhabotinsky to 15 years of hard labor, but violent protests in Palestine, England and America forced the British authorities to first mitigate, and then completely overturn the sentence [1].

At the $12^{\text {th }}$ Zionist Congress (September 1921, Carlsbad), V. Zhabotinsky was re-elected to the executive committee of the World Zionist Organization. But he quickly developed ideological differences with the majority, including Weizmann's leader.

V. Zhabotinsky also sharply opposed the socialist ideas prevailing in the Zionist movement, pointing out that the class struggle undermines the national unity necessary for the Jews. He put forward the slogan: "only one flag" and compared the combination of socialism and Zionism with the worship of two Gods at once. V. Zhabotinsky proclaimed the need to revise traditional Zionism, whence the name of the current led by him: revisionism.

On the Arab question, V. Zhabotinsky and the revisionists, in contrast to Weizmann, who was inclined to diplomatic methods, and especially in contrast to the Arabophile current in $\mathrm{Zi}$ onism, advocated the need for the development of Jewish paramilitary structures and severe forceful pressure on the Arabs to force their creation, states in Palestine. According to V. Zhabotinsky, peacefully, the Arabs are not ready to allow the implementation of the Zionist idea in any form out of natural patriotism. According to V. Zhabotinsky, the fight against the Arabs does not contradict the requirements of morality, because the Arabs have many countries and states, and the Jews are a people without a country and a nation-state. Therefore, the establishment of a Jewish state in Palestine is just, regardless of whether it is profitable or unprofitable for the Arabs to exercise this justice. 
V. Zhabotinsky advocated giving the Arabs full equality, but as a national minority in the Jewish state and after they agree with the existence of this state [11]. V. Zhabotinsky described this program in articles that became famous: "On the Iron Wall", "Ethics of the Iron Wall", "Critique of Zionism", "East", "Round Table with the Arabs" and others [1].

Because of his radical nationalism, anti-socialism, and reliance on power, he was criticized by left-wing European parties, calling him an "enemy of the working class," a "militarist," a "reactionary," and accusing him of fascism. Pro-fascist tendencies did sometimes manifest themselves in the revisionist movement, but V. Zhabotinsky was their principal opponent [3].

In 1923, V. Zhabotinsky resigned from the board of the World Zionist Organization in protest against the adoption of V. Churchill's "white book", which stated the impossibility of transforming Palestine into a mono-national Jewish country. In the same year, a circle of his supporters emerged, which was organized into the Union of Zionist Revisionists, headquartered in Paris. At the $15^{\text {th }}$ Congress of the World Zionist Organization, the Revisionist faction proposed declaring the creation of a Jewish state the official goal of the movement, but received no support. In 1928, the League of Struggle for the Seventh Dominion (of Jews and British sympathizers of Zionism) was formed in London with the active participation of V. Zhabotinsky, which put forward a program to turn Palestine into a British dominion.

In 1931, the revisionists obstructed the $17^{\text {th }}$ Zionist Congress, which left it and declared that they reserved the right not to carry out the decisions of the Zionist federation's leadership. Two years later, V. Zhabotinsky, appealing to the party masses, against the will of the revisionist leadership, sought the withdrawal of the Union of Zionist Revisionists from the World Zionist Organization. An attempt at reconciliation between Zhabotinsky and Ben-Gurion (as a representative of the left Zionists) did not find support among the left Zionists and failed. The final split in the Zionist movement took shape in 1935 with the formation of the New Zionist Organization under the chairmanship of V. Zhabotinsky, with the following program: the creation of a Jewish majority on both banks of the Jordan; the establishment of a Jewish state in Palestine on the basis of reason and justice in the spirit of the Torah; the repatriation to Palestine of all Jews who wish to do so; elimination of the diaspora. It was emphasized that "these goals are above the interests of individuals, groups or classes" [1].

From the revisionist movement created by V. Zhabotinsky came the modern Israeli "right", which is represented by the "Likud" bloc and since the 70s of the XX century has played a significant role in the political life of Israel.

When Hitler came to power in Germany (1933), V. Zhabotinsky called for a global boycott of German goods and also opposed the agreement of the Jewish Agency with the German government on the transfer to Palestine of property of German Jews who were going there.

At the Congress in Vienna in September 1935, the New Zionist Organization emerged, with V. Zhabotinsky as its president.

Simultaneously with his great organizational and ideological work, V. Zhabotinsky continued his literary activity: he published works on the problems of Judaism and the Zionist movement in various languages, and translated works of classics of European and American literature into Hebrew.

The autobiographical novel "The Five" (1936) in Russian depicts the tragic fate of an assimilated Jewish family in Odessa in 1905, one of the best prose works of the period. However, it hardly attracted the attention of critics, but was republished in Russia and Belarus in the 2000. Published memoirs "The Tale of My Days" in Hebrew [1].

For Ukrainians V. Zhabotinsky is interesting because of understanding the Ukrainian question of bilateral relations. In choosing nationalism, he understood it as a great life idea that had nothing to do with chauvinism, racism, or any form of ethical supremacy.

Dreaming of a Jewish state, he also sympathized with those who dreamed of a Ukrainian one. For this he was disgraced by some figures from among his fellow tribesmen.

Back in tsarist Russia, V. Zhabotinsky called on Jews to support local national movements, especially the Ukrainian one. After all, I understood: conscious Ukrainians can become allies in the fight against the Black Hundred.

In many ways, he was a genius seer, predicting: "It is safe to say that resolving the dispute over Russia's national character depends entirely on the position of the 30 million Ukrainian people. If nation agrees - Russia will go one way, disagree - it will have to go the other way" [11]. 
Concerned about the national interests of Jewry, the politician linked the prospects for him in our country with the support of his fellow tribesmen of the Ukrainian national movement. He considered it useful for his own people.

V. Zhabotinsky was painfully worried that Ukrainians do not value their native language, which is gradually dying $[1,17]$.

V. Zhabotinsky collaborated with the Ukrainian editions "Ukrainian Herald", "Ukrainian Life", supported the national identity of Ukrainians in a controversy with the Russian liberal P. Struve, but for him the model of the Ukrainian was T. G. Shevchenko [18].

After the outbreak of World War II, V. Zhabotinsky left for the United States in February 1940, where he began negotiations to establish a Jewish army to fight Nazism together with Western countries.

In 1940, V. Zhabotinsky died of a heart attack in the Betar camp near New York. In a will written by him in November 1935, he asked that he be buried where he died, and that his ashes be transported to Eretz Israel only with the approval of the government of the Jewish state, of which he was sure to be established soon. Only in 1964, by the decision of the government headed by L. Eshkol, the remains of V. Zhabotinsky and his wife Ioanna were transported to Israel and buried on Mount Herzl in Jerusalem [1].

V. Zhabotinsky's movement was transformed into the Herut-Svoboda party. In Israel, he is remembered and valued, and in Tel Aviv there is the V. Zhabotinsky Institute, which deals with the perpetuation of his memory and heritage. Streets in Odessa and many cities in Israel are named after V. Zhabotinsky, including the № 481 road from Petah Tikva to Tel Aviv.

V. Zhabotinsky's merits before his nation are great. Israel Kleiner wrote: "He was struck by the fate of many sincere and selfless people: many members of the Jewish people worshiped (some still worship) the anti-Semite of Jewish origin Karl Marx, and not the Jewish patriot and altruist V. Zhabotinsky" [10].

V. Zhabotinsky, as a great Jewish patriot, was also a friend of the Ukrainian people. He had an honest, sometimes stern conversation with both people, in order for them to understand the commonality of their destiny and their tasks. Then not everyone understood him. Today there is hope for greater receptivity $[2,10]$.

In the preface to V. Zhabotinsky's collection "Selected Works on the National Question" I. Dziuba wrote: "We should live together on this earth and solve our common problems together. And in this we have good advisers in the person of those figures of Ukrainian and Jewish cultures who were hurt by the pains of both nations" [7], where V. Zhabotinsky occupies a prominent place.

\section{Discussion}

At present, the social and political activities of V. Zhabotinsky and his work as a Jewish politician, a well-known Zionist, the founder of modern Israel continue to be studied by foreign and domestic scholars.

A significant amount of literature has been published on the problem under study, which reflects the life and public activity of V. Zhabotinsky, but it appeared in the vast majority until the mid-80s and was ideologically influenced in previous years. Interpretation of certain events is presented in it within the officially permitted approaches and concepts. The literature was dominated by a unanimously positive assessment of V. Zhabotinsky's activity, which characterized his journalistic legacy, socio-political positions on the national question in general and on the Ukrainian question in particular. However, this literature was published only abroad and was republished in Ukraine only decades later. The name of V. Zhabotinsky was banned in the Soviet Union, so in Ukraine the average citizen knows almost nothing.

The results of the research can be used by historians, political scientists and other specialists to further study the socio-political activities, creativity and contribution of V. Zhabotinsky as a well-known political figure of the Jewish and Ukrainian national movement; fighter for the creation of the state of Israel; one of the leaders of the Zionist movement and the founder of the revisionist current in Zionism. Materials and conclusions of the study can be used to create works that summarize the history of political, social, national and cultural development of Ukraine, in the preparation of scientific papers, textbooks and manuals, the creation of special courses on the Jewish and Ukrainian national movement. 
The practical significance is determined by the suitability for use in the process of modern transformation of the Jewish and Ukrainian national movements by politicians, parties, public organizations, state institutions, and the media. This will accelerate the process of development of Ukraine as a free independent state, simplify the myth of eternal antagonism between Jews and Ukrainians, arguing that the millennial residence of the two people in the Ukrainian lands.

\section{Conclusions}

V. Zhabotinsky's contribution as a prominent public and political figure was manifested in the following:

1. He substantiated the issue of consolidation of Jewish political and public organizations and in 1935 put forward the Program for the Establishment of a Future Independent Jewish State of Israel in Palestine.

2. Developed a common platform on the basic principles and objectives of the Jewish national movement for the revival of statehood and the involvement of Jews from around the world.

3. As a great Jewish patriot, he developed Zionist theory and practice: the preservation of Jewish national identity, ideology and the organization of the revisionist movement.

4. He promoted, as a friend of the Ukrainian people, caring for Ukraine, the common tasks and principles of the Ukrainian and Jewish people.

\section{References}

[1] Bondarchuk, P. M. (2005). Zhabotynskyi (Zeiev) V. Ye. Entsyklopediia istorii Ukrainy. Vol. 3. Kyiv: Naukova dumka, 136.

[2] Kleiner, I. (2000). Vid natsionalizmu do universalizmu: V. Zhabotynskyi i natsionalne pytannia. Kyiv, Toronto, Edmonton: Kanadskyi In-t Ukrainskykh Studii, 183-191.

[3] Shlomo, A. (2004). Pokhodzhennia sionizmu. Moscow: «Mosty kultury», 351-352.

[4] Laker, V. (2000). Istoriia sionizma. Moscow: KRON-PRESS, 848.

[5] Zhabotynskyi, V. (1911). Nauka z Shevchenkovoho yuvileiu. Odesa. Ukrainskyi ratsionalnyi natsionalizm.

[6] Dzhonson, P. (2000). Istoriia yevreiv. Kyiv: Vydavnychyi dim «Alternatyvy», 704.

[7] Dziuba, I. (1991). Druh ukrainskoi kultury: Kilka sliv pro V. Zhabotynskoho. Publitsystyka, 11, 161-166.

[8] Zhabotynskyi, V. Bidna Sharlotta. Available at: https://ru.wikisource.org/wiki/Бедная_Шарлотта_(Жаботинский)

[9] Zhabotynskyi, V. Skazanye o pohrome. Available at: https://ru.wikisource.org/wiki/Сказание_о_погроме_(Бялик; Жаботинский)

[10] Kleiner, I. V. (1992). (Zeiev) Zhabotynskyi i ukrainske pytannia: vse liudskist u shtatakh natsionalizmu. Kyiv, Toronto, Edmonton: Kanadskyi In-t Ukrainskykh Studii, 262.

[11] Losiev, I. (2012). Symvol porozuminnia: V. Zhabotynskyi stav uosoblenniam yevreisko-ukrainskoi spivpratsi. Ukrainskyi tyzhden. Available at: https://tyzhden.ua/History/46756

[12] Shamyr, M. (1993). Narod Yzraylia y strana Yzraylia. Tel-Avyv: «Rolnyk», 126.

[13] Podolskyi, A. V. (2012). Zhabotynskyi ta ukrainski natsionalni zmahannia pershoi chverti XX st.: tsinnosti mizhetnichnykh vidnosyn. Istoriia v suchasnii shkoli, 6, 41-43.

[14] Telushkin, I. (2000). Evreiskii mir: Vazhneishie znaniia o evreiskom narode, ego istorii i religii. Moscow: «Gesharim», «Mosty kultury», 576.

[15] Smolii, V. A. (Ed.) (1997). Malyi slovnyk istorii Ukrainy. Kyiv: Lybid, 464.

[16] Nedava, Y., Sheps, Yu. (1998). Zhabotynskyi: Vekhy zhyzny. Rostov-na-Donu, 134.

[17] Feller, M. (1994). Poshuky, rozdumy y spohady yevreia, yakyi pamiataie svoikh didiv, pro yevreisko-ukrainski vzaiemyny, osoblyvo zh pro movy i stavlennia do nykh. Drohobych, 105-106.

[18] Urok yuvileiu Shevchenka. Istorychna pravda. Available at: https://www.istpravda.com.ua/articles/2012/03/9/76087/ 